\title{
Cockle as Second Intermediate Host of Trematode Parasites: Consequences for Sediment Bioturbation and Nutrient Fluxes across the Benthic Interface
}

\author{
Anaïs Richard *, Xavier de Montaudouin, Auriane Rubiello and Olivier Maire \\ UMR CNRS 5805 EPOC-OASU Station Marine d'Arcachon Université de Bordeaux, F33120 Arcachon, France; \\ xavier.de-montaudouin@u-bordeaux.fr (X.d.M.); auriane.rubiello@agrocampus-ouest.fr (A.R.); \\ olivier.maire@u-bordeaux.fr (O.M.) \\ * Correspondence: anais.richard@u-bordeaux.fr
}

check for updates

Citation: Richard, A.; de Montaudouin, X.; Rubiello, A.; Maire, O. Cockle as Second Intermediate Host of Trematode Parasites: Consequences for Sediment Bioturbation and Nutrient Fluxes across the Benthic Interface. J. Mar. Sci. Eng. 2021, 9, 749. https:// doi.org/10.3390/jmse9070749

Academic Editor: Cintia

Organo Quintana

Received: 26 May 2021

Accepted: 28 June 2021

Published: 6 July 2021

Publisher's Note: MDPI stays neutral with regard to jurisdictional claims in published maps and institutional affiliations.

Copyright: (c) 2021 by the authors. Licensee MDPI, Basel, Switzerland. This article is an open access article distributed under the terms and conditions of the Creative Commons Attribution (CC BY) license (https:/ / creativecommons.org/licenses/by/ $4.0 /)$.

\begin{abstract}
Trematode parasites are distributed worldwide and can severely impact host populations. However, their influence on ecosystem functioning through the alteration of host engineering behaviours remains largely unexplored. This study focuses on a common host parasite system in marine coastal environments, i.e., the trematode Himasthla elongata, infecting the edible cockle Cerastoderma edule as second intermediate host. A laboratory experiment was conducted to investigate the indirect effects of metacercarial infection on sediment bioturbation and biogeochemical fluxes at the sediment water interface. Our results revealed that, despite high parasite intensity, the sediment reworking and bioirrigation rates, as well as nutrient fluxes, were not impacted. This finding was unexpected since previous studies showed that metacercarial infection impairs the physiological condition of cockles and induces a mechanical obstruction of their feet, thus altering their burrowing capacity. There are several explanations for such contrasting results. Firstly, the alteration of cockle behavior could arise over a longer time period following parasite infection. Secondly, the modulation of cockle bioturbation by parasites could be more pronounced in older specimens burying deeper. Thirdly, the intensity of the deleterious impacts of metacercariae could strongly vary across parasite species. Lastly, metacercarial infection alters cockle fitness through an interaction with other biotic and abiotic environmental stressors.
\end{abstract}

Keywords: Cerastoderma edule; sediment reworking; bioirrigation; nutrient fluxes; metacercariae; Himasthla elongata

\section{Introduction}

Parasites represent $40 \%$ of the total known animal species, infecting autotrophic and heterotrophic hosts in all terrestrial and aquatic environments [1,2]. These ubiquitous organisms can profoundly impact ecosystem functioning, both directly by affecting ecosystem properties and indirectly by changing the functional role of their hosts [3]. More precisely, indirect effects may result from the limitation of dominant or keystone host species abundance (i.e., density-mediated effects) or from the modification of host-specific activities, which disproportionally influence ecosystem processes and functions (i.e., traitmediated effects) [4-7]. To date, the indirect ecological consequences, at the ecosystem level, of parasite-induced engineering behavior alteration (sensu Jones et al. [8]) remain poorly known and quantified, particularly in marine environments with contradictory observations depending on the studied processes and host-parasite system. Yet, it seems particularly important to assess how and to what extent parasites can indirectly influence ecosystem functioning, as climate change, particularly global warming, is expected to strongly enhance parasite expansion and transmission, decrease host resistance, and overall exacerbate detrimental effects $[9,10]$.

A common marine parasite-host system, Himasthla elongata-Cerastoderma edule, was used in controlled laboratory experiments to investigate the potential indirect effects 
of parasite infection on second intermediate host engineering behaviors and, through cascade pathways, on benthic ecosystem processes. The common cockle Cerastoderma edule is an infaunal bivalve widespread in shallow coastal waters along the north-east Atlantic coast [11]. Cockles are particularly abundant in sandy intertidal substrates of sheltered areas such as estuaries and bays, where the population densities can reach several thousand individuals per square meter [12]. Living buried a few centimeters below the sediment-water interface, this engineer species seems a particularly good model in this framework since it influences the physical and chemical properties of the surrounding sediment through biodeposition and bioturbation [13-16], thereby playing an important ecological role in the functioning of coastal ecosystems [17]. The process of bioturbation involves both the transport of organic and inorganic particulate matter (i.e., sediment reworking) and the displacement of porewater and solutes within the sediment column and across the sediment-water interface (i.e., bioirrigation) [18]. Overall, the biomixing of particles and porewater deeply alters the characteristics (e.g., granulometry, porosity, and permeability) of the sediment matrix and enhances the incorporation of sedimented organic matter $[19,20]$. It also increases the oxygen penetration and profoundly modifies the spatiotemporal sequence of oxidants, thus stimulating microbially mediated nutrient regeneration processes [21,22].

Himasthla is one of the most common genera of trematodes using bivalve as a second intermediate host $[23,24]$. Trematodes are common macroparasites in the coastal environment [25]. Their prevalence and abundance are especially high in mollusk benthic communities [26]. They exhibit a complex life cycle involving three host species [27]. Adult trematodes reproduce in vertebrates and spawn their eggs in the environment. These eggs evolve into free-living larvae and infect the first intermediate host (generally a mollusk). Each larva metamorphoses into a sporocyst, in which free-living cercariae are produced by asexual multiplication. The cercariae emerge from the first host, penetrate the second intermediate host (an invertebrate or vertebrate), and evolve into metacercariae (latent stage). Finally, the life cycle is completed when the second intermediate host is predated by the final host (a vertebrate). Trematode parasites, by definition, exert a negative impact on their host, at the individual and/or population scale, but the intensity of the impact tightly depends on parasite species, abundance, prevalence (percentage of infested host), and parasitic stage $[25,28]$. Indeed, the sporocyst form invades most of the first intermediate host tissues, and, even though the prevalence is generally low, it induces dramatic effects on the host such as castration, growth impairment, or death [29-33]. By contrast, the pathogenicity of metacercariae is usually considered low in the second intermediate host $[25,34]$, although deleterious physiological effects have been reported in benthic invertebrates such as the blue mussel [35] or the estuarine crab Calappa granulate [36]. Alteration of the host condition can represent a strong energetic disadvantage, which may decrease growth rates and reproduction capacities, as well as increase mortality and, thus, modify population dynamics (i.e., density-mediated effects). Such density-mediated effects have been reported in C. edule infected with H. elongata [37,38] caused by disturbance of biochemical performances [39,40], leading to a reduction in growth rate [41,42] and the triggering of a high immune response [43]. Indirect trait-mediated effects have also been observed in different trematode parasite-host systems [44-46], thereby making them more vulnerable to predators, especially the final host of parasites. However, only very few studies have investigated the indirect consequences of parasite-induced host behavior modulation on ecosystem functioning [47-49].

The present study aimed to investigate whether infection with Himasthla elongata affects the bioturbation activity (sediment reworking and/or bioirrigation processes) of their second intermediate host, the cockle C. edule, and, through cascading effects, oxygen and inorganic nutrient exchanges across the sediment-water interface. Following previous studies (e.g., [25,50-52]), we hypothesized a reduction in the thickness of the bioturbated sediment layer, as well as in the intensity of sediment reworking and bioirrigation processes. In consequence, a reduction in organic matter remineralization rates and nutrient fluxes 
across the benthic boundary were expected in the presence of parasitized cockles, compared to nonparasitized conspecifics.

\section{Materials and Methods}

\subsection{Field Sampling}

Specimens of Cerastoderma edule and sediment ( $\sim 80 \mathrm{~L})$ were collected by hand in August 2020 on an intertidal flat at "Ile aux Oiseaux", Arcachon Bay, France (44 42'15.4" $\left.\mathrm{N}, 1^{\circ} 11^{\prime} 05.1^{\prime \prime} \mathrm{W}\right)$. In the laboratory, cockle shell length was measured to the lesser mm using a digital caliper, and cockles were selected according to their size. A total of 280 individuals ranging in size from 9 to $14 \mathrm{~mm}$, corresponding to young cockles characterized by a low natural trematode infection [34], were stored in tanks with running seawater $\left(\sim 20^{\circ} \mathrm{C}\right)$ for two days. The fresh sediment was sieved through a $1 \mathrm{~mm}$ mesh to remove macrofauna, larger debris, and shells, homogenized, and kept in separate tanks with seawater from the sampling site at ambient temperature for one day. Periwinkles (Littorina littorea) were collected in July 2020 in Norsminde Fjord (Denmark), where the prevalence of $H$. elongata is usually high. In the laboratory, periwinkles were individually kept in small plastic containers filled with seawater and exposed to constant artificial white light for $12 \mathrm{~h}$ to induce cercaria emergence [53]. Parasitized periwinkles were identified under a stereomicroscope by the presence of cercariae swimming in seawater. They were then maintained in aquaria at $15{ }^{\circ} \mathrm{C}$ to avoid cercaria emission and regularly fed with green macroalgae (Ulva spp.) until the experimental infection of cockles.

\subsection{Experimental Infection}

Two days after field sampling, 240 cockles were randomly selected and evenly distributed among 20 containers $(14 \mathrm{~cm} \times 9 \mathrm{~cm} \times 3 \mathrm{~cm})$ filled with $350 \mathrm{~mL}$ of seawater (salinity $=31.5,20^{\circ} \mathrm{C}$ ), corresponding to 12 cockles per container. In 10 containers, three periwinkles infected by the trematode Himasthla elongata were immediately introduced in each container [51]. They were continuously illuminated by artificial white light for $24 \mathrm{~h}$ (the seawater temperature then rapidly increased to $24^{\circ} \mathrm{C}$ ) to stimulate the emission of cercariae, which encysted in cockles, their second intermediate host. Cockles were left undisturbed for $6 \mathrm{~h}$ in a $15{ }^{\circ} \mathrm{C}$ tempered room following periwinkle removal in order to allow complete encystment of metacercarial larvae. The same protocol was conducted in 10 containers without periwinkles. The whole experimental process was reiterated three days later to ensure a higher and more homogeneous cockle infection and to avoid cercaria virulence variability across $H$. elongata strains $[54,55]$.

\subsection{Experimental Procedure}

Twenty-eight experimental units (PVC tube, height $30 \mathrm{~cm}$, internal diameter $9.3 \mathrm{~cm}$ ) filled with $20 \mathrm{~cm}$ of homogenized sieved sediment were placed in a tidal mesocosm, which consisted of a large tank containing $600 \mathrm{~L}$ of natural seawater. An artificial tidal regime ( $6 \mathrm{~h}$ low tide $/ 6 \mathrm{~h}$ high tide) was generated by pumping $200 \mathrm{~L}$ of water in a second tank, corresponding to a variation in the water level of about $20 \mathrm{~cm}$. The transition between high and low tide lasted about $3 \mathrm{~min}$ and was carefully adjusted in order to avoid sediment resuspension. The seawater temperature $\left(19 \pm 1^{\circ} \mathrm{C}\right)$ and salinity $(33 \pm 1)$ remained constant throughout the entire duration of the experiment. After two days of sediment stabilization, seven cockles that were not experimentally infested (nonparasitized "NP" treatment) were placed on the sediment surface of 12 experimental units (i.e., a total of 84 nonparasitized cockles) while seven cockles which were experimentally infested (parasitized " $\mathrm{P}$ " treatment), were also placed on the sediment surface of 12 other experimental units (i.e., a total of 84 parasitized cockles) ( $n=12$ for both "NP" and "P" treatments). Cockles displayed the same shell length distribution among the different experimental units. The corresponding density $\left(1030 \mathrm{ind} \cdot \mathrm{m}^{-2}\right)$ was in the range commonly reported in the field for individuals of similar shell length [56-58]. Additionally, four control units were kept without cockles. At the beginning of the experiment, three days after the introduction 
of cockles, $10 \mathrm{~g}$ of luminophores (fluorescent particle tracers, $\mathrm{d}_{50}=250 \mu \mathrm{m}, 2.6 \mathrm{~g} \cdot \mathrm{cm}^{-3}$ density) was homogeneously spread at the sediment-water interface of each experimental unit (sediment reworking analysis). Simultaneously, $630 \mathrm{~g}$ of sodium bromide ( $\mathrm{NaBr}$ ) was dissolved in the water of the tidal mesocosm (bioirrigation analysis). All experimental units were incubated in the tidal mesocosm during nine days following the addition of particulate and dissolved tracers.

\subsection{Sediment Characteristics}

The sediment grain size was determined using a laser diffraction microgranulometer (Malverns Panalytical ${ }^{\circledR}$ Mastersizer hydro 2000G, Malvern, UK). The proportion of the mud fraction $(<63 \mu \mathrm{m})$ and the median grain size $\left(\mathrm{d}_{50}\right)$ were used as synthetic parameters. Sediment organic carbon (OC) and total nitrogen (TN) contents were assessed on freezedried homogenized samples. For OC measurement, the sediment was decarbonated with $1.2 \mathrm{~N} \mathrm{HCl}[59]$. OC and TN were analyzed using a CN auto-analyzer (Thermoscientific FlashSmart, Bremen, Germany). Sediment porosity was assessed in an additional experimental unit. At the end of the experiment, the sediment column was vertically sliced into $0.5 \mathrm{~cm}$ thick layers from the surface to $5 \mathrm{~cm}$ depth and into $1 \mathrm{~cm}$ thick layers between 5 and $11 \mathrm{~cm}$ depth. Slices were weighted and then dried at $60^{\circ} \mathrm{C}$ for four days. The loss of water (assessed by the difference between wet and dry weight) was corrected for sea-salt content assuming a sediment bulk density of $2.65 \mathrm{~g} \cdot \mathrm{cm}^{-3}[60]$.

\subsection{Benthic Flux Measurement}

After nine days, oxygen $\left(\mathrm{O}_{2}\right)$, ammonium $\left(\mathrm{NH}_{4}{ }^{+}\right)$, nitrates and nitrites $\left(\mathrm{NO}_{2}{ }^{-}+\mathrm{NO}_{3}{ }^{-}\right.$, noted hereafter as $\left.\mathrm{NO}_{\mathrm{x}}\right)$, and dissolved silicate $(\mathrm{dSi})$ fluxes across the sediment-water interface were quantified in total darkness. Twenty milliliters of overlying water was sampled in each microcosm for the measurement of initial nutrient concentrations, just before they were hermetically sealed with a PVC lid. The $\mathrm{O}_{2}$ concentration was then continuously measured using a mini-optode (OXROB10, Pyroscience ${ }^{\circledR}$, Aachen, Allemagne) connected to a Firesting Oxygen Meter (Pyroscience ${ }^{\circledR}$, Aachen, Allemagne) placed through the lid $5 \mathrm{~cm}$ above the sediment surface. The optode was previously linearly calibrated between the oxygen concentration of the overlying water (100\% saturation) measured by Winkler titration [61] and zero oxygen in a sodium ascorbate solution. A constant homogenization of the overlying water was ensured by a Teflon-coated magnetic stirring bar ( 100 rpm) attached to the lid. As soon as the $\mathrm{O}_{2}$ concentration reached $75 \%$ of its initial value, the incubation was stopped, and the overlying water was sampled for final nutrient measurements using a Quattro-AXFLOW auto-analyzer (Norderstedt, Germany).

The total oxygen uptake (TOU) and nutrient fluxes $\left(\mathrm{mmol} \cdot \mathrm{m}^{-2} \cdot\right.$ day $\left.^{-1}\right)$ were finally computed from concentration decreases within each experimental unit, according to the following equation:

$$
\text { Fluxes }=(\mathrm{a} \times \mathrm{V}) /(\mathrm{S}) \text {, }
$$

where $a$ is the slope $\left(\mathrm{mmol} \cdot \mathrm{m}^{-3} \cdot \mathrm{day}^{-1}\right)$ of $\mathrm{O}_{2}$ or nutrient concentrations as a function of time (day), $V$ is the volume of overlying water $\left(\mathrm{m}^{3}\right)$, and $S$ is the surface area of the sediment-water interface $\left(\mathrm{m}^{2}\right)$.

\subsection{Quantification of Bioturbation Rates \\ 2.6.1. Bioirrigation}

All experimental units were vertically drilled on one side at $1 \mathrm{~cm}$ intervals. For the duration of the experiment, the openings ( $2 \mathrm{~mm}$ diameter) were sealed with a strip of hydrophobic adhesive tape. Immediately following biogeochemical flux measurements, $500 \mu \mathrm{L}$ of porewater was extracted at 0.5 to $11.5 \mathrm{~cm}$ depth with rhizon samplers (length $9 \mathrm{~cm}$, mean pore size $0.15 \mu \mathrm{m}$ ) and stored at $4{ }^{\circ} \mathrm{C}$ until analyses. After oxidization with chloramine- $\mathrm{T}$ in the presence of phenol red, bromide concentrations were determined spectrophotometrically by fitting the absorbance measured at $595 \mathrm{~nm}$ to a standard curve $[62,63]$. 
An enhanced diffusion factor $(\varepsilon)$ was then estimated by fitting vertical bromide profiles with the enhanced diffusion model [64]. The tracer concentration $C(\mathrm{mM})$ in the sediment is described by Equation (2).

$$
\phi \frac{\partial C}{\partial t}=\frac{\partial}{\partial x}\left(\varepsilon D_{s} \phi \frac{\partial C}{\partial x}\right)
$$

where $C$ is the bromide concentration in the sediment $(\mathrm{mM}), t$ is the incubation time (day), $x$ is the depth in the sediment $(\mathrm{cm}), D_{s}$ is the molecular diffusion coefficient, $\phi$ is the porosity, and $\varepsilon$ is a factor of enhanced diffusion (i.e., $\varepsilon$ is equal to 1 when solute transport is exclusively driven by molecular sediment diffusion). $\varepsilon$ was estimated by convergent iterations and weighted least-squared regressions of model prediction on observed vertical bromide profiles.

\subsubsection{Sediment Reworking}

Immediately after porewater sampling, the sediment column was vertically sliced into $0.5 \mathrm{~cm}$ thick layers from the surface to $5 \mathrm{~cm}$ depth. During slicing, cockles were gently removed and kept for parasite diagnosis (see below). The sediment of each slice was then freeze-dried and homogenized. A subsample of $3 \mathrm{~g}$ was spread in a Petri dish and photographed under UV light using a digital camera (Nikon ${ }^{\circledR}$ D100, Tokyo, Japan) fitted with a yellow filter. Luminophore pixels were counted for each image after a binarization step (based on the RGB level) using AviExplore software [65].

Sediment reworking rates $\left(D_{b}, \mathrm{~cm}^{2} \cdot\right.$ year $\left.^{-1}\right)$ were computed by fitting a one-dimensional biodiffusive model to luminophore vertical profiles (see [66] for further details) according to Equation (3).

$$
\frac{\partial C}{\partial t}=D b \frac{\partial^{2} C}{\partial z^{2}}
$$

where $C$ is the proportion of luminophore (\%), $t$ is the time (year), and $z$ is the vertical depth in the sediment column $(\mathrm{cm}) \cdot D_{b}\left(\mathrm{~cm}^{2} \cdot\right.$ year $\left.{ }^{-1}\right)$ was estimated as a function of convergent iterations and weighted least-squared regressions of model prediction on observed vertical luminophore profiles. In addition, the proportion of the sediment surface reworked by the cockles (PRS) was assessed by analyzing pictures of experimental units taken at the beginning and at the end of the experiment (i.e., just before benthic flux measurements) using AviExplore software [65].

\subsection{Parasite Diagnosis}

The 168 cockles were measured once more and dissected for trematode inspection. The flesh was removed from the shell, squeezed between two glass slides, and observed under a stereomicroscope. Metacercariae, all belonging to the Himasthla genus, were counted in the whole body.

\subsection{Data Analysis}

Results are generally reported as the mean \pm standard error (SE) of $n$ replicate measurements. A Wilcoxon-Mann-Whitney nonparametric test was used to compare the total abundance of metacercariae belonging to the Himasthla genus in "nonparasitized" $(n=84)$ and "parasitized" $(n=84)$ cockles. Differences among treatments ("control" $(n=4)$, "nonparasitized" ( $n=12)$, and "parasitized" $(n=12))$ concerning bioturbation rates (both bioirrigation and sediment reworking) and biogeochemical fluxes (oxygen, ammonium, nitrates and nitrites, and silicate) were assessed using one-way analysis of variance (ANOVA). Prior to analysis, the homogeneity of variance and the normality were tested using Levene and Shapiro tests, respectively. For bioirrigation, sediment reworking, and proportion of reworked surface (PRS), these conditions were not respected, and the data were transformed using the Boxcox function to compute an optimal power transformation. A pairwise $t$-test was performed when the ANOVA was significant $(p<0.05)$ using Bonferroni correction ( $p$-value adjusted for multiple comparisons), to determine which treatment differed. A Kruskal-Wallis test was conducted for bioirrigation depth only when conditions of appli- 
cation were not respected despite transformation. Lastly, a principal component analysis (PCA) was applied to the entire standardized data (bioturbation rates and biogeochemical fluxes at the sediment water-interface) to explore a possible correlation between measured variables and treatments (NP vs. P). All statistical analyses were performed using the open-source program R (v3.6.1) in R studio (v1.3.1056) (www.R-project.org, accessed on 1 August 2020.

\section{Results}

\subsection{Parasite Diagnosis}

Visual observations carried out throughout the experiment revealed that both nonparasitized ("NP") and parasitized (" $\mathrm{P}$ ") cockles buried rapidly $(<1 \mathrm{~h})$ and remained just below the sediment surface for most of the 9-day period. Nonparasitized cockles were slightly naturally infected with $4.5 \pm 0.4$ metacercariae per individual. In contrast, parasitized cockles were significantly more infected with $74.2 \pm 6.5$ metacercariae per individual (Wilcoxon, $p<0.001$ ). No additional parasite species were present in both parasitized and nonparasitized cockles. All cockle specimens were found alive during core slicing at the end of the experiment.

\subsection{Sediment Characteristics}

The sediment consisted of a muddy fine sand $\left(d_{50}=235 \mu \mathrm{m}\right)$, composed of $24 \%$ mud. Sediment organic carbon (OC) and total nitrogen (TN) contents were $0.37 \%$ OC and $0.04 \%$ TN. Sediment porosity slightly varied with depth, and the top $5 \mathrm{~cm}$ had an average porosity of $0.332 \pm 0.005$.

\subsection{Bioturbation}

\subsubsection{Bioirrigation}

The natural background concentration of bromide in seawater of Arcachon bay was $0.8 \mathrm{mM}$. About $30 \mathrm{~min}$ following $\mathrm{NaBr}$ addition, the tracer concentration in the water of the tidal mesocosm was $11 \mathrm{mM}$. At the end of the experiment, the natural background concentration was reached at $6.0 \pm 0.3 \mathrm{~cm}$ in the control treatment and at $6.7 \pm 0.2$ and $6.7 \pm 0.3 \mathrm{~cm}$ in the experimental units inhabited by nonparasitized and parasitized cockles, respectively, with no significant difference among the three treatments (Kruskal-Wallis test, $p=0.25)$. The distribution of excess $\mathrm{Br}^{-}$in all experimental units exponentially decreased with depth (Figure 1A).

A)

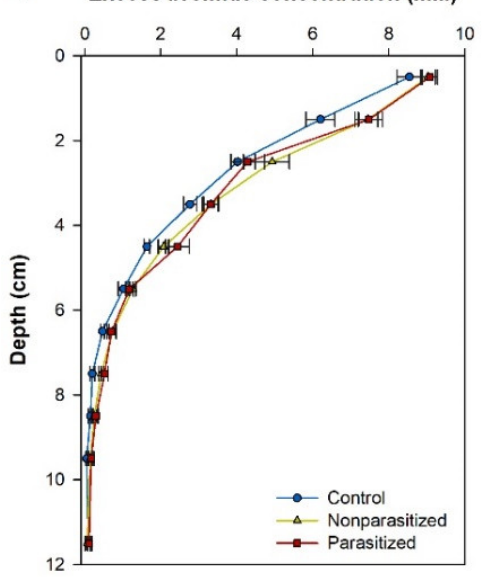

B)

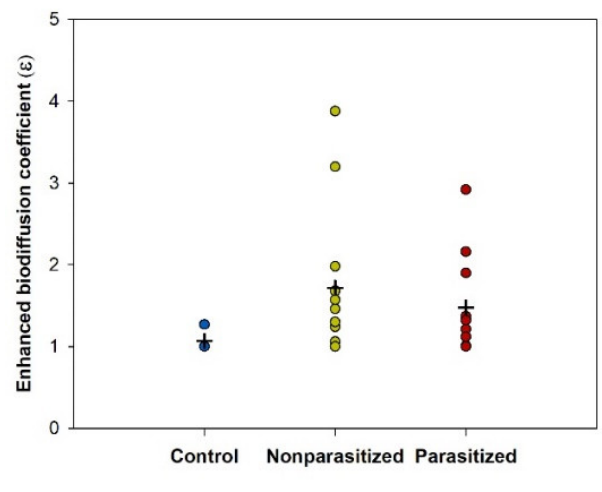

Figure 1. (A) Excess bromide concentration profiles in sediment cores (mean $\pm \mathrm{SE}$ ), and (B) modeled factor of enhanced biodiffusion $(\varepsilon)$ (data are represented by points; black crosses correspond to the mean value) following nine days of incubation for the three treatments ("control" $(n=4)$, "nonparasitized" $(n=12)$, and "parasitized" $(n=12))$. 
In control units, the average value of the enhanced diffusion coefficient $(\varepsilon)$ was very close to $1(1.1 \pm 0.1)$, attesting that solute transport was mainly driven by molecular diffusion (Figure 1B). In the presence of nonparasitized and parasitized cockles, $\varepsilon$ values were slightly higher ( $1.7 \pm 0.3$ and $1.5 \pm 0.2$, respectively) but differences among the three treatments were not significant (ANOVA, $p=0.23$ ), probably due to the high variability among replicates in both "NP" and " $\mathrm{P}$ " treatments.

\subsubsection{Sediment Reworking}

At the end of the experiment, all the cockles were recovered in the first centimeter of the sediment column. The final distribution of luminophores in experimental units containing cockles consistently exhibited an exponential decrease with depth (Figure 2A). Therefore, $17 \% \pm 2 \%$ and $18 \% \pm 1 \%$ of the sediment surface (PRS) was reworked in the presence of nonparasitized and parasitized cockles, respectively, and percentages were not significantly different (ANOVA, $p=0.18$ ). In both treatments, tracers were mainly buried between 0.5 and $1.5 \mathrm{~cm}$ depth and never beyond $2 \mathrm{~cm}$, thus indicating that particle mixing was restricted to the first $2 \mathrm{~cm}$ regardless of the parasitic status. Conversely, the sediment surface of control units was still entirely covered by luminophores after nine days, and $99.2 \% \pm 0.3 \%$ of them were found in the uppermost sediment layer.

A)

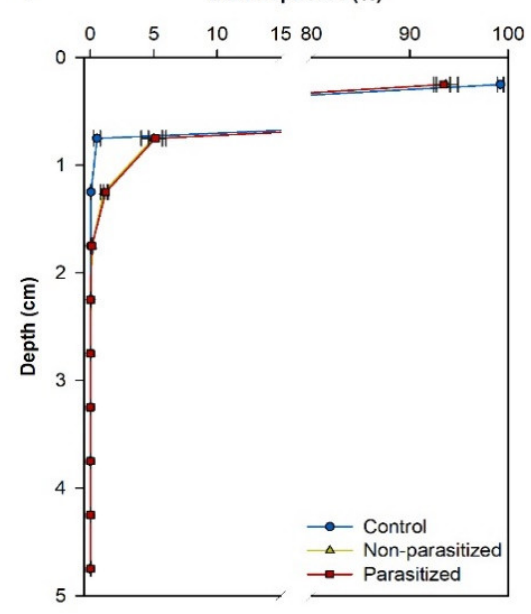

B)

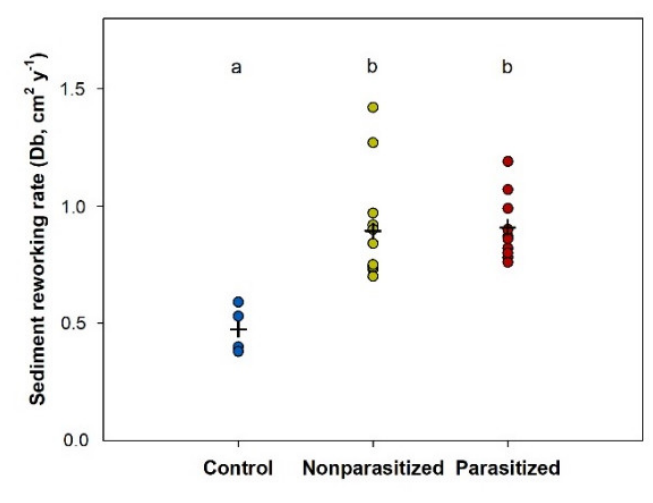

Figure 2. (A) Depth profiles of luminophores initially deposed at the surface of experimental units (mean $\pm \mathrm{SE}$ ), and $(\mathbf{B})$ sediment reworking rate $(\mathrm{Db})$ (data are represented by points; black crosses correspond to the mean value) following nine days of incubation for the three treatments ("control" $(n=4)$, "nonparasitized" $(n=12)$, and "parasitized" $(n=12))$. Different letters indicate significant differences among treatments $(p<0.05)$ after performing a pairwise $t$-test with Bonferroni correction when one-way ANOVA was significant $(p<0.05)$.

The sediment reworking rate $(\mathrm{Db})$ was higher in the presence of nonparasitized and parasitized cockles $\left(0.89 \pm 0.07\right.$ and $0.91 \pm 0.04 \mathrm{~cm}^{2} \cdot \mathrm{year}^{-1}$, respectively) than in the control treatment $\left(0.48 \pm 0.05 \mathrm{~cm}^{2} \cdot\right.$ year $\left.^{-1}\right)$ (pairwise $t$-test, $\left.p<0.001\right)$ (Figure $2 \mathrm{~B}$ ). Db values did not differ between "NP" and "P" treatments (pairwise $t$-test, $p>0.05$ ).

\subsection{Benthic Fluxes Measurements}

The total oxygen uptake (TOU) was higher in cockle treatments (averaging -35.5 \pm 1.7 and $-35.1 \pm 1.6 \mathrm{mmol} \cdot \mathrm{m}^{-2}$. day ${ }^{-1}$ in "NP" and " $\mathrm{P}$ " treatments, respectively) than in the control treatment $\left(-22.6 \pm 2.0 \mathrm{mmol} \cdot \mathrm{m}^{-2}\right.$. day $\left.{ }^{-1}\right)$ (pairwise $t$-test, $\left.p<0.01\right)$, with no effect of the parasitic condition (pairwise $t$-test, $p>0.05$ ) (Figure 3A). All nutrient fluxes were positive, indicating a net release from the sediment (Figure 3B-D). The presence of nonparasitized cockles enhanced the effluxes of $\mathrm{NH}_{4}{ }^{+}$and $\mathrm{dSi}$ across the sediment-water interface (averaging $4.1 \pm 0.5$ and $2.4 \pm 0.1 \mathrm{mmol} \cdot \mathrm{m}^{-2}$. day ${ }^{-1}$, respectively) compared to the control treatment in which they respectively averaged $0.8 \pm 0.3$ and $1.6 \pm 0.1 \mathrm{mmol} \cdot \mathrm{m}^{-2} \cdot$ day $^{-1}$ 
(pairwise $t$-test, $p<0.05$ ) (Figure 3B,D). Parasitized cockles also increased the releases of $\mathrm{NH}_{4}{ }^{+}$and $\mathrm{dSi}$, although they were not statistically different from other treatments (pairwise $t$-test, $p>0.05)$. $\mathrm{NO}_{\mathrm{x}}$ fluxes were low in the three treatments $\left(<1.5 \mathrm{mmol} \cdot \mathrm{m}^{-2}\right.$.day $\left.{ }^{-1}\right)$, with no difference among them (ANOVA, $p=0.10$ ) (Figure 3C).
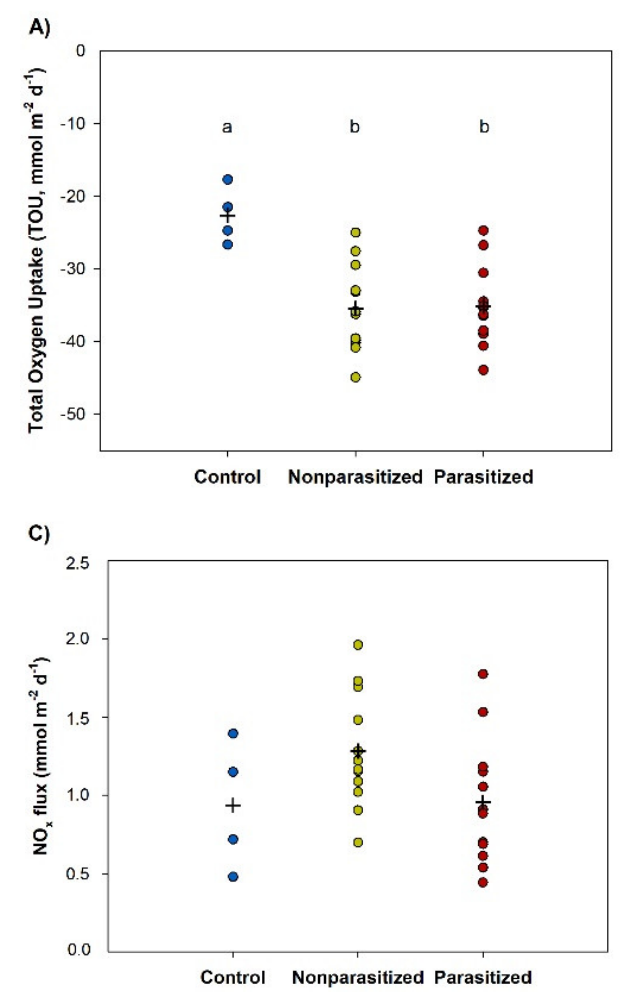
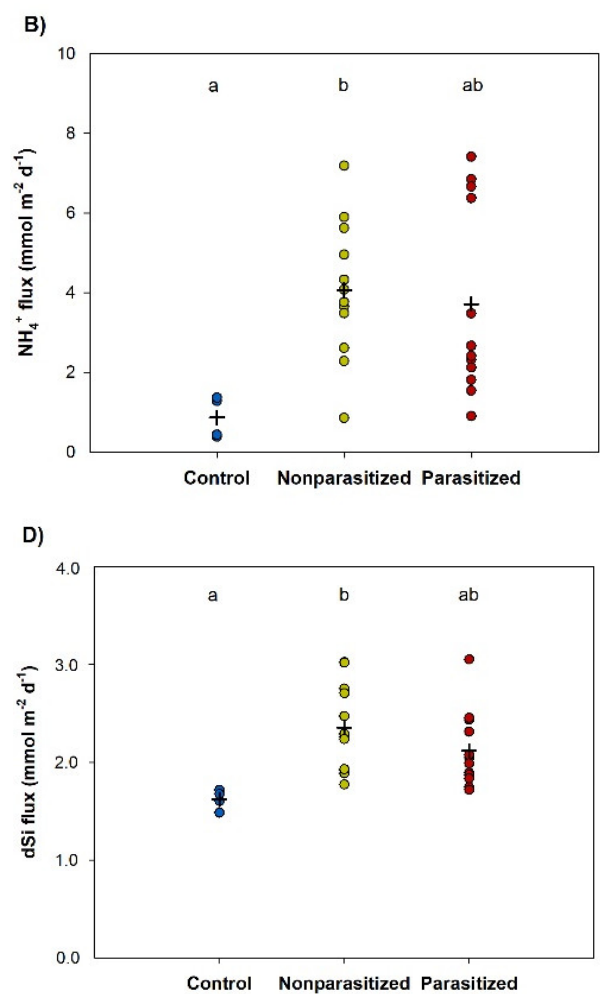

Figure 3. (A) Total oxygen uptake and fluxes of (B) ammonium, (C) nitrate and nitrite, and (D) dissolved silicate across the sediment-water interface (data are represented by points; black crosses correspond to the mean value) for the three treatments ("control" $(n=4)$, "nonparasitized" $(n=12)$, and "parasitized" $(n=12))$. Different letters indicate significant differences $(p<0.05)$ among treatments after performing a pairwise $t$-test with Bonferroni correction when one-way ANOVA was significant $(p<0.05)$.

\subsection{Principal Component Analysis}

The first dimension of the PCA explained $43.5 \%$ of the total inertia, and the second dimension explained $27.4 \%$ (Figure 4). The $\mathrm{NH}_{4}{ }^{+}$(percentage contribution to dimension 1: $24 \%$ ) and dSi fluxes (31\%) and were both positively associated with the first dimension, whereas TOU (22\%) was negatively correlated. This dimension discriminated the control treatment, characterized by low oxygen consumption and effluxes of $\mathrm{NH}_{4}{ }^{+}$and $\mathrm{dSi}$, from the experimental units with nonparasitized and parasitized cockles. However, "NP" and "P" treatments were not strongly differentiated, with the gravity center of "NP" corresponding to slightly higher values of the first dimension than the " $\mathrm{P}$ " treatment. Concerning the second dimension, $\mathrm{NO}_{\mathrm{x}}$ fluxes $(26 \%)$ and $\varepsilon(44 \%)$ were respectively positively and negatively correlated. There was no net difference among the three treatments regarding the second dimension. Only the gravity center of the " $\mathrm{P}$ " treatment corresponded to negative values of this dimension. Lastly, the contribution of $\mathrm{Db}$ was too low to characterize one of the two dimensions, even if a negative correlation with TOU could be noted. 

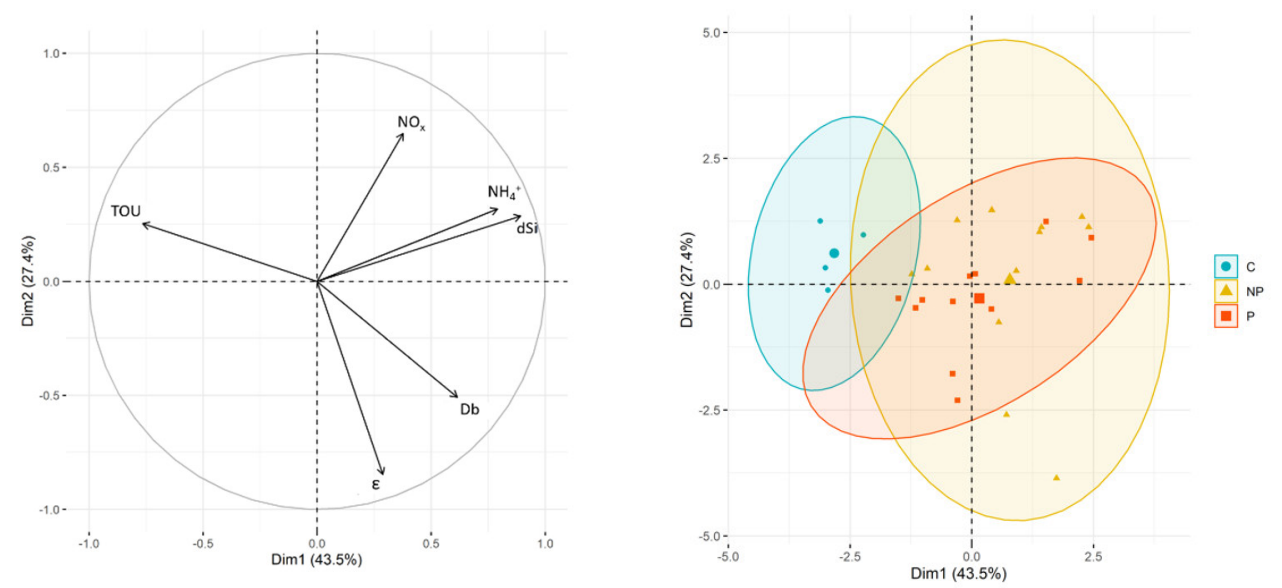

Figure 4. Principal component analysis (PCA) of standardized data. Black arrows represent the projection of measured variables (sediment reworking rates $(\mathrm{Db})$, bioirrigation rates $(\varepsilon)$, total oxygen uptake (TOU), and ammonium $\left(\mathrm{NH}_{4}{ }^{+}\right)$, nitrates and nitrites $\left(\mathrm{NO}_{\mathrm{x}}\right)$, and silicate $(\mathrm{dSi})$ fluxes) on the first plane of the PCA. Points correspond to experimental units including the three treatments ("control" treatment (C) in the blue circle, "nonparasitized" cockles (NP) in the yellow triangle, and "parasitized" cockles (P) in the red square). Larger points represent the gravity center of each group corresponding to a treatment, and lines show the confidence ellipse at the 0.95 level.

\section{Discussion}

The abundance of metacercarial larvae observed in experimentally infected cockles was 16-fold higher than that in noninfected specimens, indicating that (1) the experimental infection procedure was efficient, allowing high parasite intensity to be attained, and (2) the parasitic status between the two treatments (nonparasitized, NP vs. parasitized, P) was highly contrasted. Moreover, the abundance of $H$. elongata in parasitized cockles was in the upper part of the range commonly reported in the field [24,67] or recorded in previous experimental studies [39-41]. Despite this high infection rate, we found that metacercarial larvae impacted neither the mode of bioturbation generated by cockles nor its intensity. Indeed, the exponential shape of both luminophore and bromide depth profiles revealed that, irrespective of the parasitic status, particle and solute transports were mainly driven by diffusive-like processes [64,68]. Parasitized cockles, thus, behaved as nonparasitized conspecifics, inducing a constant and random biomixing of the first $2 \mathrm{~cm}$ of the sediment column characteristic of surficial biodiffusors [18]. Sediment reworking rates measured per gram dry weight were similar in the two treatments $\left(8.09\right.$ and $8.21 \mathrm{~cm}^{2} \cdot$ year $^{-1} \cdot \mathrm{g} \mathrm{DW}^{-1}$ in NP and P treatments, respectively) and slightly higher than those previously reported for the same species by Mermillod-Blondin et al. [69] $\left(2.14 \mathrm{~cm}^{2} \cdot\right.$ year $\left.^{-1} \cdot \mathrm{g} \mathrm{DW}^{-1}\right)$. They were also on the same order of magnitude as other infaunal suspension-feeding bivalves such as the clam Polititapes aureus [70]. Similarly, the bioirrigation activity of nonparasitized and parasitized cockles during the nine days of the experiment was not different. $\varepsilon$ values (1.7 \pm 0.3 and $1.5 \pm 0.2$ in NP and P treatments, respectively) indicate that solute displacements were low, mainly driven by molecular diffusion in most experimental units, regardless of parasite intensity. The weak influence of C. edule on porewater movement can be explained by its shallow burying depth (especially in young specimens), as well as its feeding mode. Indeed, as a suspension-feeder, it directly pumps water with its inhalant siphon just above the sediment surface so that the overlying water transported through the paleal cavity is not in contact with the surrounding sediment [69]. Porewater movements are, thus, mainly generated by shell-valve abduction (i.e., opening of the valves to allow the siphons to extend) and closure of the exhalant siphon, which both induce limited pressurization of the sediment over short periods of time [71]. However, while the influence of cockles on sediment bioirrigation was not genuinely perceptible using bromides at the timescale of the experiment, the high degree of variance of $\varepsilon$ values, as well as the 
enhancement of dSi efflux, observed during benthic flux measurement revealed that these burrowing bivalves, irrespective of their parasitic condition, can nonetheless periodically increase the exchange of solutes between interstitial and overlying waters. As observed for bioturbation processes, parasitic infection with $H$. elongata did not impact the influence of its second intermediate host on biogeochemical fluxes across the sediment-water interface. Therefore, the sediment total oxygen uptake (TOU), which mainly results from the (1) organic carbon remineralization via aerobic microbial respiration, (2) reoxidation of reduced products from anaerobic degradation, and (3) macrofaunal respiration [72], was very similar in the two treatments $\left(-35.5 \pm 1.7\right.$ and $-35.1 \pm 1.6 \mathrm{mmol} \cdot \mathrm{m}^{-2} \cdot$ day $^{-1}$ in NP and $\mathrm{P}$ treatments, respectively). Estimation of the bivalve oxygen consumption based on the length/weight allometric relationship [38] and the respiration/AFDW equation developed by Newell \& Bayne [73] suggested that the TOU increase observed in the presence of young cockles was largely due to their own respiration $(96 \% \pm 6 \%$ and $99 \% \pm 6 \%$ in NP and $\mathrm{P}$ treatments, respectively) rather than the stimulation of diagenetic processes through sediment bioturbation. This was confirmed by the very low intensity of NOx effluxes, suggesting that nitrification was not significantly stimulated despite the higher ammonium concentrations in both treatments. This also highlighted that the contribution of cockles to nutrient fluxes across the sediment-water interface in both NP and P treatments mainly resulted from the direct excretion of metabolic wastes (e.g., ammonium) [13,74]. Our findings are consistent with previous studies which showed that shallow-burrowing filter-feeders, including C. edule, have generally limited effects on porewater oxygen concentrations due to moderate bioturbation rates, and they consequently induce low modifications of sediment microbial-mediated processes [13,75-77]. However, although the oxygen consumption by encysted larvae is negligible [78], Magalhães et al. [40] observed that, two days following H. elongata metacercarial infection, cockles can drastically reduce their respiration rate. In the present study, the absence of discernable effects of trematodes on TOU 12 days after infection (and, thus, on oxygen consumption by parasitized cockles since bioturbation rates were similar between the two treatments) reinforces the interpretation of the authors that these immediate effects following encystment reflect a quick defense mechanism rather than a direct long-term impact of parasites on the host oxygen requirement. The absence of significant effects of parasites on sediment bioturbation and biogeochemical dynamics is in contrast with our a priori predictions. Indeed, although the biochemical and physiological effects of trematode parasites are usually much more detrimental on their first than second intermediate hosts $[29,31,33,42]$, recent studies nevertheless highlighted that metacercarial infection can have profound metabolic consequences [39,40,48]. For example, Magalhães et al. [79] observed a strong increase in energetic reserve (e.g., glycogen content) of infected cockles, thus reflecting an enhanced metabolic activity to cope with parasiteinduced additional energetic requirement, as well as fuel defense mechanisms. Moreover, several experimental or field studies demonstrated that metacercarial invasion of different trematode species such as Curtuteria australis or Himasthla spp., both using infaunal bivalves as a second intermediate host, can induce a mechanical obstruction of their feet, thereby potentially altering their burrowing capacity $[50,80,81]$. This has been interpreted as a behavioral manipulation aimed at increasing the transmission rate to the final host (e.g., a shorebird) that preferentially feeds on surface-dwelling prey. Therefore, we anticipated that infected cockles would remain buried less deep and/or would strongly reduce their lateral displacement. Since the volume of sediment and porewater displaced by burrowing suspension-feeding bivalves fundamentally depends on burying depth and movement distance [15], we expected lower bioturbation rates in parasitized specimens. As an indirect consequence, through a cascading effect, we anticipated a reduction in oxygen penetration depth into the sediment, leading to reduced remineralization rates and inorganic nutrient fluxes toward the overlying water. Such negative indirect effects of parasites on benthic ecosystem functioning through an alteration of host bioturbation activity have been, for example, recently quantified in another marine parasite-host system Upogebia pusilla-Gyge branchialis [7]. However, it is interesting to note that parasite infection can also have the 
opposite effect. Indeed, Williams et al. [6] showed that infected individuals of Gammarus duebeni with an acanthocephalan parasite, Polymorphus minutus, surprisingly increased their digging activity, thereby reworking an extended sediment surface area compared to noninfected congeners.

Several assumptions can be formulated to explain the absence of significant indirect effects of metacercariae on sediment bioturbation and nutrient fluxes observed during the present study. Firstly, trait-mediated indirect effects would be more obvious and pronounced in older host specimens, which bury deeper into the sediment $[82,83]$. We chose young bivalves, in which parasite intensity is naturally low, as a model host to ensure contrasted experimental parasitic conditions between our NP and P treatments. However, the bioturbation potential of young cockles is limited due to their low burrowing depth, which does not exceed 1-2 cm compared to 5-6 $\mathrm{cm}$ in adults [84]. Therefore, the resolution of vertical tracer profiles every $0.5 \mathrm{~cm}$ may not be fine enough to allow for accurate detection of weak alteration both particle and solute transport just below the sediment-water interface. Secondly, deleterious behavioral effects caused by metacercariae would appear over a longer-term period. For example, Bakhmet et al. [85] only observed a significant impact of $H$. elongata metacercarial infection on the heart rate of the blue mussel Mytilus edulis after 12 months. Thirdly, the degree of pathogenicity and the intensity of host responses are species-specific. Hence, Magalhães et al. [40] showed that the effects of trematode infection on host metabolic activities tightly depend on the parasite species. The effects of $H$. elongata infection would, thus, be less deleterious or may require a longer time period to arise than for other larval stages or species, such as Bucephalus minimus, which quickly reduces the bioturbation potential of $C$. edule, as well as their influence on the sediment stability [16]. Lastly, parasites alter the fitness of their second intermediate host via interactions with other biotic and abiotic environmental stressors. Paul-pont et al. [43], for instance, reported that the impact of $H$. elongata metacercarial infection on C. edule defense-related performance profoundly depended on its combination with other biotic (e.g., Vibrio tapetis) or abiotic (e.g., cadmium) stressors.

\section{Conclusions}

The present study suggests that the parasitic alteration of the biochemical and physiological performance of an ecosystem engineer host species does not necessarily translate into marked behavioral changes with obvious consequences for ecosystem functioning. Nevertheless, to better understand the ecological role played by trematode parasites in marine benthic ecosystem processes (e.g., bioturbation) and functions (e.g., nutrient recycling), it would be interesting to further investigate the potential long-term effects of metacercarial infection on older and larger host specimens, which more intensively interact with their physical and chemical environments, by considering the possible interactions with other trematode species or other sources of stress.

Author Contributions: Conceptualization, A.R. (Anaïs Richard), O.M. and X.d.M.; investigation and formal analysis, A.R. (Anaïs Richard), O.M., A.R. (Auriane Rubiello) and X.d.M.; writing-original draft preparation, A.R. (Anaïs Richard); writing-review and editing, A.R. (Anaïs Richard), O.M. and X.d.M. All authors read and agreed to the published version of the manuscript.

Funding: This research was funded by the INTERREG-ATLANTIC program through the research project COCKLES (EAPA_458/2016 COCKLES: Cooperation for restoring cockle shellfisheries and their ecosystem services in the Atlantic Area). This work is part of Anaïs Richard's doctoral thesis (University of Bordeaux - 2018-SG-D-13) financed by a doctoral grant of the French “Ministère de l'Enseignement Supérieur et de la Recherche".

Institutional Review Board Statement: Not applicable.

Informed Consent Statement: Not applicable.

Data Availability Statement: The data presented in this study are available on request from the corresponding authors. 
Acknowledgments: We would like to thank the captain and the crewmembers of R/V Planula IV (CNRS-INSU-FOF) and K. Thomas Jensen for their help during field work. We would also like to thank Marie-Ange Cordier, Nicolas Savoye, Nathalie Labourdette, and Marie-Claire Perello for their assistance with laboratory work, Stéphane Paulin-Henricksson for his help during the computation of bioirrigation rates and to Irwine William (MDPI) for correcting the English of our manuscript.

Conflicts of Interest: The authors declare no conflict of interest. The funders had no role in the design of the study; in the collection, analyses, or interpretation of data; in the writing of the manuscript, or in the decision to publish the results.

\section{References}

1. Dobson, A.; Lafferty, K.D.; Kuris, A.M.; Hechinger, R.F.; Jetz, W. Homage to Linnaeus: How many parasites? How many hosts? Proc. Natl. Acad. Sci. USA 2008, 105, 11482-11489. [CrossRef]

2. Johnson, P.T.J.; Ostfeld, R.S.; Keesing, F. Frontiers in research on biodiversity and disease. Ecol. Lett. 2015, 18, 1119-1133. [CrossRef]

3. Preston, D.L.; Mischler, J.A.; Townsend, A.R.; Johnson, P.T.J. Disease Ecology Meets Ecosystem Science. Ecosystems 2016, 19, 737-748. [CrossRef]

4. Mouritsen, K.N.; Poulin, R. Parasitism, community structure and biodiversity in intertidal ecosystems. Parasitology 2002, 124, 101-117. [CrossRef]

5. Sato, T.; Egusa, T.; Fukushima, K.; Oda, T.; Ohte, N.; Tokuchi, N.; Watanabe, K.; Kanaiwa, M.; Murakami, I.; Lafferty, K.D. Nematomorph parasites indirectly alter the food web and ecosystem function of streams through behavioural manipulation of their cricket hosts. Ecol. Lett. 2012, 15, 786-793. [CrossRef] [PubMed]

6. Williams, M.A.; Donohue, I.; Picard, J.; O'Keeffe, F.; Holland, C.V. Infection with behaviour-manipulating parasites enhances bioturbation by key aquatic detritivores. Parasitology 2019, 146, 1528-1531. [CrossRef] [PubMed]

7. Pascal, L.; Grémare, A.; Montaudouin, X.; Deflandre, B.; Romero-Ramirez, A.; Maire, O. Parasitism in ecosystem engineer species: A key factor controlling marine ecosystem functioning. J. Anim. Ecol. 2020, 89, 2192-2205. [CrossRef] [PubMed]

8. Jones, C.G.; Lawton, J.H.; Moshe, S. Organisms as Ecosystem Engineers. Oikos 1994, 69, 373-386. [CrossRef]

9. Harvell, C.D.; Mitchell, C.E.; Ward, J.R.; Altizer, S.; Dobson, A.P.; Ostfeld, R.; Samuel, M.D. Climate Warming and Disease Risks for Terrestrial and Marine Biota. Science 2002, 296, 2158-2162. [CrossRef]

10. Marcogliese, D.J. The impact of climate change on the parasites and infectious diseases of aquatic animals. Rev. Sci. Tech. L'oie 2008, 27, 467-484. [CrossRef]

11. Malham, S.K.; Hutchinson, T.H.; Longshaw, M. A review of the biology of European cockles (Cerastoderma spp.). J. Mar. Biol. Assoc. U. K. 2012, 92, 1563-1577. [CrossRef]

12. Tyler-Walters, H. Cerastoderma edule Common Cockle. In Marine Life Information Network: Biology and Sensitivity Key Information Reviews; Hiscock, K., Tyler-Walters, H., Eds.; Marine Biological Association of the United Kingdom: Plymouth, UK, 2007.

13. Swanberg, I.L. The influence of the filter-feeding bivalve Cerastoderma edule L. on microphytobenthos: A laboratory study. J. Exp. Mar. Biol. Ecol. 1991, 151, 93-111. [CrossRef]

14. Ciutat, A.; Widdows, J.; Readman, J. Influence of cockle Cerastoderma edule bioturbation and tidal-current cycles on resuspension of sediment and polycyclic aromatic hydrocarbons. Mar. Ecol. Prog. Ser. 2006, 328, 51-64. [CrossRef]

15. Rakotomalala, C.; Grangeré, K.; Ubertini, M.; Forêt, M.; Orvain, F. Modelling the effect of Cerastoderma edule bioturbation on microphytobenthos resuspension towards the planktonic food web of estuarine ecosystem. Ecol. Model. 2015, 316, 155-167. [CrossRef]

16. Dairain, A.; Maire, O.; Meynard, G.; Orvain, F. Does parasitism influence sediment stability? Evaluation of trait-mediated effects of the trematode Bucephalus minimus on the key role of cockles Cerastoderma edule in sediment erosion dynamics. Sci. Total Environ. 2020, 733, 139307. [CrossRef] [PubMed]

17. Carss, D.N.; Brito, A.C.; Chainho, P.; Ciutat, A.; de Montaudouin, X.; Otero, R.M.F.; Filgueira, M.I.; Garbutt, A.; Goedknegt, M.A.; Lynch, S.A.; et al. Ecosystem services provided by a non-cultured shellfish species: The common cockle Cerastoderma edule. Mar. Environ. Res. 2020, 158, 104931. [CrossRef] [PubMed]

18. Kristensen, E.; Penha-Lopes, G.; Delefosse, M.; Valdemarsen, T.; Quintana, C.; Banta, G. What is bioturbation? The need for a precise definition for fauna in aquatic sciences. Mar. Ecol. Prog. Ser. 2012, 446, 285-302. [CrossRef]

19. Krantzberg, G. The influence of bioturbation on physical, chemical and biological parameters in aquatic environments: A review. Environ. Pollut. Ser. A Ecol. Biol. 1985, 39, 99-122. [CrossRef]

20. Volkenborn, N.; Polerecky, L.; Wethey, D.; DeWitt, T.; Woodin, S. Hydraulic activities by ghost shrimp Neotrypaea californiensis induce oxic-anoxic oscillations in sediments. Mar. Ecol. Prog. Ser. 2012, 455, 141-156. [CrossRef]

21. Aller, R.C. The Effects of Macrobenthos on Chemical Properties of Marine Sediment and Overlying Water. In Animal-Sediment Relations; McCall, P., Tevesz, M.J.S., Eds.; Springer US: Boston, MA, USA, 1982; pp. 53-102. [CrossRef]

22. Aller, R.C. Sedimentary Diagenesis, Depositional Environments, and Benthic Fluxes. Treatise Geochem. 2014, 8, 293-334. [CrossRef]

23. De Montaudouin, X.; Kisielewski, I.; Bachelet, G.; Desclaux, C. A census of macroparasites in an intertidal bivalve community, Arcachon Bay, France. Oceanol. Acta 2000, 23, 453-468. [CrossRef] 
24. Thieltges, D.W.; Krakau, M.; Andresen, H.; Fottner, S.; Reise, K. Macroparasite community in molluscs of a tidal basin in the Wadden Sea. Helgol. Mar. Res. 2006, 60, 307-316. [CrossRef]

25. Lauckner, G. Diseases of Mollusca: Bivalvia. In Diseases of Marine Animals; Kinne, O., Ed.; Biologische Anstalt Helgoland: Hamburg, Germany, 1983; Volume 2.

26. De Montaudouin, X.; Thieltges, D.W.; Gam, M.; Krakau, M.; Pina, S.; Bazairi, H.; Dabouineau, L.; Russell-Pinto, F.; Jensen, K.T. Digenean trematode species in the cockle Cerastoderma edule: Identification key and distribution along the north-eastern Atlantic shoreline. J. Mar. Biol. Assoc. U. K. 2009, 89, 543-556. [CrossRef]

27. Esch, G.W.; Barger, M.A.; Fellis, K.J. The Transmission of Digenetic Trematodes: Style, Elegance, Complexity. Integr. Comp. Biol. 2002, 42, 304-312. [CrossRef]

28. Poulin, R.; Combes, C. Interactions Durables: Ecologie et Evolution du Parasitisme. J. Parasitol. 1997, 83, 177. [CrossRef]

29. Da Silva, P.M.; Magalhães, A.R.; Barracco, M.A. Effects of Bucephalus sp. (Trematoda: Bucephalidae) on Perna perna mussels from a culture station in Ratones Grande Island, Brazil. J. Invertebr. Pathol. 2002, 79, 154-162. [CrossRef]

30. Thieltges, D.W. Parasite Induced Summer Mortality in the Cockle Cerastoderma edule by the Trematode Gymnophallus choledochus. Hydrobiologia 2006, 559, 455-461. [CrossRef]

31. Dubois, S.; Savoye, N.; Sauriau, P.; Billy, I.; Martinez, P.; De Montaudouin, X. Digenean trematodes-marine mollusc relationships: A stable isotope study. Dis. Aquat. Org. 2009, 84, 65-77. [CrossRef]

32. Magalhães, L.; Freitas, R.; De Montaudouin, X. Review: Bucephalus minimus, a deleterious trematode parasite of cockles Cerastoderma spp. Parasitol. Res. 2015, 114, 1263-1278. [CrossRef]

33. Magalhães, L.; Daffe, G.; Freitas, R.; De Montaudouin, X. Monorchis parvus and Gymnophallus choledochus: Two trematode species infecting cockles as first and second intermediate host. Parasitology 2020, 147, 643-658. [CrossRef]

34. De Montaudouin, X.; Binias, C.; Lassalle, G. Assessing parasite community structure in cockles Cerastoderma edule at various spatio-temporal scales. Estuar. Coast. Shelf Sci. 2012, 110, 54-60. [CrossRef]

35. Bakhmet, I.; Nikolaev, K.; Levakin, I. Effect of infection with Metacercariae of Himasthla elongata (Trematoda: Echinostomatidae) on cardiac activity and growth rate in blue mussels (Mytilus edulis) In Situ. J. Sea Res. 2017, 123, 51-54. [CrossRef]

36. Robaldo, R.; Monserrat, J.; Cousin, J.; Bianchini, A. Effects of metacercariae (Digenea: Microphallidae) on the hepatopancreas of Chasmagnathus granulata (Decapoda: Grapsidae). Dis. Aquat. Org. 1999, 37, 153-157. [CrossRef]

37. Desclaux, C.; De Montaudouin, X.; Bachelet, G. Cockle Cerastoderma edule population mortality: Role of the digenean parasite Himasthla quissetensis. Mar. Ecol. Prog. Ser. 2004, 279, 141-150. [CrossRef]

38. Gam, M.; De Montaudouin, X.; Bazairi, H. Do trematode parasites affect cockle (Cerastoderma edule) secondary production and elimination? J. Mar. Biol. Assoc. U. K. 2009, 89, 1395-1402. [CrossRef]

39. Magalhães, L.; de Montaudouin, X.; Figueira, E.; Freitas, R. Interactive effects of contamination and trematode infection in cockles biochemical performance. Environ. Pollut. 2018, 243, 1469-1478. [CrossRef]

40. Magalhães, L.; Freitas, R.; de Montaudouin, X. How costly are metacercarial infections in a bivalve host? Effects of two trematode species on biochemical performance of cockles. J. Invertebr. Pathol. 2020, 177, 107479. [CrossRef]

41. Wegeberg, A.M.; Jensen, K.T. In Situ growth of juvenile cockles, Cerastoderma edule, experimentally infected with larval trematodes (Himasthla interrupta). J. Sea Res. 2003, 50, 37-43. [CrossRef]

42. De Montaudouin, X.; Bazairi, H.; Culloty, S. Effect of trematode parasites on cockle Cerastoderma edule growth and condition index: A transplant experiment. Mar. Ecol. Prog. Ser. 2012, 471, 111-121. [CrossRef]

43. Paul-Pont, I.; Gonzalez, P.; Baudrimont, M.; Jude, F.; Raymond, N.; Bourrasseau, L.; Le Goïc, N.; Haynes, F.; Legeay, A.; Paillard, C.; et al. Interactive effects of metal contamination and pathogenic organisms on the marine bivalve Cerastoderma edule. Mar. Pollut. Bull. 2010, 60, 515-525. [CrossRef]

44. Helluy, S.; Thomas, F. Effects of Microphallus papillorobustus (Platyhelminthes: Trematoda) on serotonergic immunoreactivity and neuronal architecture in the brain of Gammarus insensibilis (Crustacea: Amphipoda). Proc. R. Soc. B Boil. Sci. 2003, 270, 563-568. [CrossRef]

45. Seppälä, O.; Karvonen, A.; Valtonen, E.T. Parasite-induced change in host behaviour and susceptibility to predation in an eye fluke-fish interaction. Anim. Behav. 2004, 68, 257-263. [CrossRef]

46. Seppälä, O.; Karvonen, A.; Valanko, E.T. Host manipulation by parasites and risk of non-host predation: Is manipulation costly in an eye fluke-fish interaction? Evol. Ecol. Res. 2006, 8, 871-879.

47. Lefevre, T.; Lebarbenchon, C.; Gauthier-Clerc, M.; Missé, D.; Poulin, R.; Thomas, F. The ecological significance of manipulative parasites. Trends Ecol. Evol. 2008, 24, 41-48. [CrossRef] [PubMed]

48. Vannatta, J.T.; Minchella, D.J. Parasites and their impact on ecosystem nutrient cycling. Trends Parasitol. 2018, $34,452-455$. [CrossRef] [PubMed]

49. Dairain, A.; Legeay, A.; De Montaudouin, X. Influence of parasitism on bioturbation: From host to ecosystem functioning. Mar. Ecol. Prog. Ser. 2019, 619, 201-214. [CrossRef]

50. Thomas, F.; Poulin, R. Manipulation of a mollusc by a trophically transmitted parasite: Convergent evolution or phylogenetic inheritance? Parasitology 1998, 116, 431-436. [CrossRef]

51. Jensen, K.T.; Castro, N.F.; Bachelet, G. Infectivity of Himasthla spp. (Trematoda) in cockle (Cerastoderma edule) spat. J. Mar. Biol. Assoc. U. K. 1999, 79, 265-271. [CrossRef] 
52. Mouritsen, K.N.; Poulin, R. Parasites boosts biodiversity and changes animal community structure by trait-mediated indirect effects. Oikos 2005, 108, 344-350. [CrossRef]

53. De Montaudouin, X.; Blanchet, H.; Desclaux-Marchand, C.; Lavesque, N.; Bachelet, G. Cockle infection by Himasthla quissetensis-I. From cercariae emergence to metacercariae infection. J. Sea Res. 2016, 113, 99-107. [CrossRef]

54. Seppälä, O.; Karvonen, A.; Valtonen, E.T. Phenotypic Variation in Infectivity of Diplostomum spathaceum cercariae within a population. J. Parasitol. 2007, 93, 1244-1246. [CrossRef] [PubMed]

55. Hapman, J.R.; Nakagawa, S.; Coltman, D.; Slate, J.; Heldon, B.C. A quantitative review of heterozygosity-fitness correlations in animal populations. Mol. Ecol. 2009, 18, 2746-2765. [CrossRef] [PubMed]

56. De Montaudouin, X. Factors involved in growth plasticity of cockles Cerastoderma edule (L.), identified by field survey and transplant experiments. J. Sea Res. 1996, 36, 251-265. [CrossRef]

57. Dabouineau, L.; Ponsero, A. Synthèse Sur la Biologie des Coques Cerastoderma edule, 2nd ed.; Réserve Naturelle Baie de St-Brieuc; CCSD: Villeurbanne, France, 2009; pp. 1-24.

58. Magalhães, L.; Correia, S.; de Montaudouin, X.; Freitas, R. Spatio-temporal variation of trematode parasites community in Cerastoderma edule cockles from Ria de Aveiro (Portugal). Environ. Res. 2018, 164, 114-123. [CrossRef] [PubMed]

59. Kennedy, P.; Kennedy, H.; Papadimitriou, S. The effect of acidification on the determination of organic carbon, total nitrogen and their stable isotopic composition in algae and marine sediment. Rapid Commun. Mass Spectrom. 2005, 19, 1063-1068. [CrossRef]

60. Burdige, D.J. Geochemistry of Marine Sediments; Princeton University Press: Princeton, NJ, USA, 2006.

61. Grasshoff, K.; Ehrhardt, M.; Kremling, K. Methods of Seawater Analysis, 3rd ed.; Wiley-VCH: Weinheim, Germany, 1999.

62. Hannides, A.K.; Dunn, S.M.; Aller, R.C. Diffusion of organic and inorganic solutes through macrofaunal mucus secretions and tube linings in marine sediments. J. Mar. Res. 2005, 63, 957-981. [CrossRef]

63. Lepore, B.J.; Barak, P. A Colorimetric Microwell Method for Determining Bromide Concentrations. Soil Sci. Soc. Am. J. 2009, 73, 1130-1136. [CrossRef]

64. Andersson, J.H.; Middelburg, J.J.; Soetaert, K. Identifiability and uncertainty analysis of bio-irrigation rates. J. Mar. Res. 2006, 64, 407-429. [CrossRef]

65. Romero-Ramirez, A.; Grémare, A.; Bernard, G.; Pascal, L.; Maire, O.; Duchene, J. Development and validation of a video analysis software for marine benthic applications. J. Mar. Syst. 2016, 162, 4-17. [CrossRef]

66. Maire, O.; Lecroart, P.; Meysman, F.; Rosenberg, R.; Duchêne, J.; Grémare, A. Quantification of sediment reworking rates in bioturbation research: A review. Aquat. Biol. 2008, 2, 219-238. [CrossRef]

67. Wegeberg, A.M.; de Montaudouin, X.; Jensen, K. Effect of intermediate host size (Cerastoderma edule) on infectivity of cercariae of three Himasthla species (Echinostomatidae, Trematoda). J. Exp. Mar. Biol. Ecol. 1999, 238, 259-269. [CrossRef]

68. Meysman, F.J.R.; Galaktionov, O.S.; Gribsholt, B.; Middelburg, J.J. Bio-irrigation in permeable sediments: An assessment of model complexity. J. Mar. Res. 2006, 64, 589-627. [CrossRef]

69. Mermillod-Blondin, F.; Rosenberg, R.; Carcaillet, F.; Norling, K.; Mauclaire, L. Influence of bioturbation by three benthic infaunal species on microbial communities and biogeochemical processes in marine sediment. Aquat. Microb. Ecol. 2004, 36, 271-284. [CrossRef]

70. François, F.; Dalègre, K.; Gilbert, F.; Stora, G. Variabilité spécifique à l'intérieur des groupes fonctionnels. Étude du remaniement sédimentaire de deux bivalves Veneridae, Ruditapes decussatus et Venerupis aurea. C. R. Acad. Sci. Ser. III Sci. Vie 1999, 322, 339-345. [CrossRef]

71. Woodin, S.A.; Volkenborn, N.; Pilditch, C.A.; Lohrer, A.M.; Wethey, D.; Hewitt, J.E.; Thrush, S.F. Same pattern, different mechanism: Locking onto the role of key species in seafloor ecosystem process. Sci. Rep. 2016, 6, 26678. [CrossRef]

72. Glud, R.N. Oxygen dynamics of marine sediments. Mar. Biol. Res. 2008, 4, 243-289. [CrossRef]

73. Newell, R.I.E.; Bayne, B.L. Seasonal changes in the physiology, reproductive condition and carbohydrate content of the cockle Cardium (=Cerastoderma) edule (Bivalvia: Cardiidae). Mar. Biol. 1980, 56, 11-19. [CrossRef]

74. Sandwell, D.R.; Pilditch, C.A.; Lohrer, A.M. Density dependent effects of an infaunal suspension-feeding bivalve (Austrovenus stutchburyi) on sandflat nutrient fluxes and microphytobenthic productivity. J. Exp. Mar. Biol. Ecol. 2009, 373, 16-25. [CrossRef]

75. Henriksen, K.; Rasmussen, M.B.; Jensen, A. Effect of bioturbation on microbial nitrogen transformations in the sediment and fluxes of ammonium and nitrate to the overlaying water. Ecol. Bull. 1983, 35, 193-205.

76. Magni, P.; Montani, S.; Takada, C.; Tsutsumi, H. Temporal scaling and relevance of bivalve nutrient excretion on a tidal flat of the Seto Inland Sea, Japan. Mar. Ecol. Prog. Ser. 2000, 198, 139-155. [CrossRef]

77. Camillini, N.; Larsen, M.; Glud, R. Behavioural patterns of the soft-shell clam Mya arenaria: Implications for benthic oxygen and nitrogen dynamics. Mar. Ecol. Prog. Ser. 2019, 622, 103-119. [CrossRef]

78. Vernberg, W.B.; Vernberg, F.J. Respiratory Metabolism of a Trematode Metacercaria and Its Host. Aspeas of the Biology of Symbiosis; Cheng, T.C., Ed.; University Park Press: Baltimore, MD, USA, 1971; pp. 91-102.

79. Magalhães, L.; De Montaudouin, X.; Figueira, E.; Freitas, R. Trematode infection modulates cockles biochemical response to climate change. Sci. Total. Environ. 2018, 637-638, 30-40. [CrossRef] [PubMed]

80. Desclaux, C.; De Montaudouin, X.; Bachelet, G. Cockle emergence at the sediment surface: "Favourization" mechanism by digenean parasites? Dis. Aquat. Org. 2002, 52, 137-149. [CrossRef] [PubMed]

81. Mouritsen, K.N. The parasite-induced surfacing behaviour in the cockle Austrovenus stutchburyi: A test of an alternative hypothesis and identification of potential mechanisms. Parasitology 2002, 124, 521-528. [CrossRef] [PubMed] 
82. Sandnes, J.; Forbes, T.; Hansen, R.; Sandnes, B.; Rygg, B. Bioturbation and irrigation in natural sediments, described by animal-community parameters. Mar. Ecol. Prog. Ser. 2000, 197, 169-179. [CrossRef]

83. Thrush, S.F.; Hewitt, J.E.; Gibbs, M.; Lundquist, C.; Norkko, A. Functional Role of large organisms in intertidal communities: Community effects and ecosystem function. Ecosystems 2006, 9, 1029-1040. [CrossRef]

84. Zwarts, L.; Wanink, J. Siphon size and burying depth in deposit- and suspension-feeding benthic bivalves. Mar. Biol. 1989, 100, 227-240. [CrossRef]

85. Bakhmet, I.; Nikolaev, K.; Levakin, I.; Ekimov, D. Influence of Himasthla elongata (Trematoda: Echinostomatidae) metacercariae on heart rate in blue mussels (Mytilus edulis). J. Invertebr. Pathol. 2019, 166, 107220. [CrossRef] 